\title{
The Newly Found Kongō-Ji Manuscript An-Ban Shou-Yi Jingl) and T602 Fo-Shuo Da An-Ban Shou-Yi Jing
}

\author{
- An Analysis of T602 to Distinguish the Original Scripture \\ from its Commentary-
}

\section{Hung-lung HuNG}

The colophon to the ASYJ, written by the editor of the Korean Canon, is also reproduced in the Taisho Tripitaka. The editor claimed in the colophon that the ASYJ is a corrupt text in which the original scripture and its commentaries are mixed in a way that makes them indistinguishable. From comparing the new found K-ASYJ to the T-ASYJ, we can easily distinguish which parts of the T-ASYJ are the original scripture and which are the commentaries. In order to research a complicated text such as the T-ASYJ, this is a very useful method. I would like to provide an example of how to distinguish which are the original texts and which are the commentaries in the following paragraph.

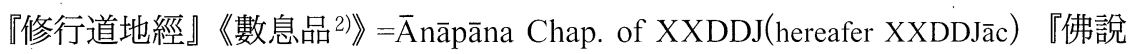
大安般守意經 ${ }^{3)} \rrbracket=T-A S Y J$

（1) 何謂修行數息守意求於督然。 $\rightarrow$ 1道人行安般守意欲止意。當何因縁得止意。 (What does it mean to practice ānāpanasati in order to search for Samatha) $\rightarrow(\mathrm{A}$ practitioner practices ānāpanasati in hoping to attain samatha. What are the causes and conditions which lead to the attainment of samatha?)

(2) 今當解說數息之法何謂數息。 $\rightarrow$ 2 聽說安般守意。

(Now I will explain ānāpanasati, what is ānāpanasati) $\rightarrow$ (I will explain ānāpanasati)

(3) 何謂為安。何謂為般。出息為安。入息為般。 $\rightarrow 3$ 何等為安。何等為般。安名 為入息。般名為出息。

(What is āna? What is apāna? Exhaling the breath is āna, Inhaling the breath is apāna) $\rightarrow$ (What is āna? What is apāna? Āna is to inhale the breath, apāna is to exhale the breath.)

Before comparing the two texts mentioned above, XXDDJāc and T-ASYJ, we must first identify two terms which are translated by An Shigao. Let us compare 
two paragraphs which occur in The 道地經Dao-Di-Jing(hereafter DDJ) and the修行 道地經Xiu-Xing-Dao-Di-Jing(hereafter XXDDJ). The DDJ of one scroll containing seven chapters, translated by An Shigao(安世高), corresponds to chaptersl-5 and chapters 22 and 24 of XXDDJ, which is translated by Zhu Fahu(筑法護). It is very likely that the two Chinese translations are derived from the same original text. ${ }^{4}$ )

Let us now examine two parallel sentences from the chapter of Miraculous Base (神足行章 of the DDJ,(hereafter DDJmb) and 神足品 of XXDDJ,(hereafter XXDDJmb). DDJmb 「行者持何等行得止意。報。若干因行止意。聽說要止意。二因縁 方便得止意。一者念惡露。二者念安般守意 ${ }^{5}$ 。」

XXDDJmb「其修行者。何因專精求入寂然。無數方便而逮於埱。今取要言而 獬説之。因二事致。一惡露觀。二曰數息守出入息 ${ }^{6)}$ 。」

From the two above parallel sentences, we can find their corresponding terminologies and their original Pāli words below

\begin{tabular}{lrl}
\hline XXDDJmb & DDJmb & Pāli word \\
寂、寂然 & 止意 & samatha \\
解說 & 聽說 & desessāmi
\end{tabular}

Usually, the pair of words“śamatha • vipaśyanā"or"samatha • vipassanā" are translated into Chinese as “止觀”, but Zhu Fahu, in most cases, translated this pair into “俶觀7)”. So we can verify, in these parallel sentences, that the original phrase “叔 然(叔)” or “止意” is equivalent to “samatha”. Moreover, to provide another example of word usage we can use another text, 是法非法經 Shi-fa Fei-fa Jing and (hereafter SFFFJ) translated by An Shigao. It is also a very literal and crude rendering, parallels the Chinese translation 中阿含·真人經 Zhong Ahan-Zhen Ren Jing (hereafter ZAH-ZRJ) tanslated by 矍曇僧伽提婆 Ju-Tan Seng-Qie Ti-Po, both of which are translations of the same Pāli text, Sappurisasuttam.

SFFFJ :「比丘從佛聽佛說。有賢者法。比丘聽說。亦有非賢者法。」 (T.48,p.837c25-26)

ZAH-ZRJ : [我今為汝說真人法及不真人法。」(T.26,p.561a23-24)

Sappurisasuttam $^{8]}:$ Bhagavā etadavoca-“sappurisadhammañca vo, bhikkhave, desessāmi asappurisadhammañca.

We can see that the original Pāli term desessāmi is translated to 廳說] in SFFFJ and to 我今為汝說 in ZAH-ZRJ. The word desessāmi is the First Person, 
Indicative Future form of deseti, which means to show, to point out, or to explain. So the meaning of desessāmi is "I will show you ......" and has the same meaning as the Chinese term “當解說” in XXDDJāc. Now let us compare the terms in sentences (1)(2) and (12 of XXDDJāc and T-ASYJ with XXDDJmb and DDJmb:

$\begin{array}{lllll}\text { XXDDJāc } & \text { T-ASYJ } & \text { XXDDJmb } & \text { DDJmb } & \text { Pāli word } \\ \text { (1)寂然 } & \text { 1止意 } & \text { 惄、寂然 } & \text { 止意 } & \text { samatha } \\ \text { (2)當解說 } & \text { 2 聽說 } & \text { 解說 } & \text { 聽說 } & \text { desessāmi }\end{array}$

Let us note the term 聽說 and 止意 in Taisho Tripitaka. In most cases, we find that An Shigao, out of all other potential translators ${ }^{9)}$, utilized these two terms the most. Even though we have not confirmed that all the instances where terms 聽說 and 止意 appear originate from the pāli word desessāmi and samatha , by observing the frequency that An Shigao used these terms, it is no doubt sentences 12 in TASYJ were translated by him. In addition, we find another term 道人 ${ }^{10)}$, which appears in numerous texts that An Shigao translated ${ }^{11)}$.

We find that the content in the seven chapters of DDJ can correspond to its parallel text of the XXDDJ's. We can therefore claim that the XXDDJ contains all of the original text, whereas DDJ is a simplified version of the original. An Shigao should have knowledge of all the original text of XXDDJ, however he only translated seven chapters from it. Therefore, the three $\operatorname{sentences}(\mathbf{1} \sim(3)$ in T-ASYJ should have come from the same original text as XXDDJāc does.

\section{The definition of 安 Ana and 般Apāna}

Regarding the relationship of the above-mentioned three sentences in the XXDDJāc and T-ASYJ, a Japanese scholar Aramaki Noritoshi 荒牧典俊(1971) ${ }^{12)}$ pointed out already that both paragraphs in XXDDJāc and T-ASYJ are correspondent to each other ${ }^{13)}$. Moreover, he said that the several sentences of T-ASYJ probably were extracted and translated together with the DDJ by An Shigao, from the original text of XXDDJ(=Yogācābhūmi) compiled by Saṃgharakṣa. But Aramaki only offered the conclusion; he didn't demonstrate any examples, and moreover he didn't notice the variation between these two texts.

In(3)of XXDDJāc, it reads "Exhaling the breath is āna, inhaling the breath is apāna." But in 3 of T-ASYJ, the definition is just the opposite, as it says, "āna is to in- 
hale the breath, apāna is to exhale the breath." What is the reason for this contradiction ? Please note the following paragraphs from the 大毘婆沙論 ${ }^{14)}$ and the 順正理 論 ${ }^{15)}$, which displays the different definition of the terms āna and apāna, according to three different theories in the 大毘婆沙論 and two theories in the 順正理論.

Regarding the definition of 安 āna and 般 apāna, we find that in both 大毘婆沙 論 and 順正理論, the masters of Sarvāstivāda share the same theory. That is 安 $=$ 阿那 $=\bar{a} n a=$ 持来 $=$ 持息入 $=$ 入息 般 $=$ 阿波那 $=a p a \bar{n} a=$ 持去 $=$ 持息出 $=$ 出息

And we find in 大毘婆沙論, both 有作是説(Some Say) and 有餘師說(The Other Masters Say) share the same theory, we find出息(breathe out) is equal to 煖息(warm breath), as when human beings breathe out, the sensation of the breath is warm. Similarly, we find 入息(breathe in) is equal to 冷息(cool breath), as when human beings breathe in, the sensation of the breath is cool.

Therefore, we find 'Some Say' = 'The Other Masters Say', both share the same theory :

持来 (keep coming in $)=$ 出息(breathe out $)=$ 煖息(warm breath)

持去(keep going out) =入息(breathe in)=冷息(cool breath)

When we compare 大毘婆沙論 with 順正理論, the theory of The Other Masters Say becomes very clear :

阿那 $=\bar{a} n a=$ (能)持来 $=$ 出息 $=$ 煖息

阿波那 $=a p \bar{a} n a=$ (能)持去 $=$ 入息 $=$ 冷息

Finally, we find two contradicting theories occurring in Abhidharma Buddhism, which are on the one hand, the theory of the Sarvāstivādin masters:

$\underline{\text { anna }=\text { breathe in, apāna }=\text { breathe out }}$

and on the other hand, the theory of The Other Masters Say:

$\underline{\text { anna=breath out, } \text { apāna }=\text { breath in }}$

What is 有餘師 “The Other Masters”? According to 『俱舍論記16)』 written by 普光Pu-Guang, “The Other Masters” mainly refers to 經部師 Jing-bushi(Sutrāntika).

Furthermore, according to 印順法師 ${ }^{17)}$ Yin-sun Fa-shi(1992), Samgharakșa, the author of XXDDJ is a 譬喻師(Dārștantika). And after 大毘婆沙論 had been edited, Dārștantika separated from Sarvāstivāda and became 經部 Jing-bu or 經量部 Jing- 
liang-bu (=Sutrāntika $)^{18)}$. Since 譬喻師(Dārștantika) did not become an independent group from Sarvāstivāda until after the Abhidharma era, it's viewpoint is the same as 經部師 Jing-bu-shi(Sutrāntika) or 有餘師(The Other Masters).

Therefore, the definition of 安 āna and 般 apāna in XXDDJ differs from TASYJ. Just the opposite, the definition of 安 Ana and 般 apAna in T-ASYJ is the same as K-ASYJ. Let us again compare both texts below. ${ }^{19)}$

\section{T-ASYJ 3 何等為安。何等為般。安名為入息。般名為出息。}

K-ASYJ 何等為安。何等為般。何等為安般守意。入息為安。出息為般 ${ }^{20)}$ 。

If we omit the term 「何等為安般守意」, the two passages are almost identical to each other. We find in front of T-ASYJ 3 the (2聽說安般守意 already appears, so it is rational that An Shigao omitted “何等為安般守意” to simplify the text. Therefore, T-ASYJ 3 had been cited directly from the original text K-ASYJ by An Shigao.

\section{Conclusion}

From the terminology and content of the aforementioned two texts, we can say that the three sentences in T-ASYJ were translated and edited by An Shigao himself. Those three sentences are very similar to the paragraph in XXDDJāc. Therefore, An Shigao cited this paragraph from the original text of the XXDDJāc in order to interpret (3)何等為安。何等為般。安名為入息。般名為出息. Moreover, the sentence (3 何等為安。何等為般。安名為入息。般名為出息 is derived from the KASYJ's original texts. Why are sentence 3 of the T-ASYJ not identical to those of K-ASYJ? The reason is that An Shigao's works can be divided into two kinds. ${ }^{21}$ One kind is 口解, oral interpretation, the other is 文傳, or literal rendering. We find the T-ASYJ is an oral interpretation just likes『阿含口解十二因緣經 ${ }^{22) 』(T .1508), ~}$ whereas K-ASYJ is a simplified literal rendering.

1) The Newly Found Text of the An Ban Shou Yi Jing Translated by An Shigao was discovered by Mr. Kajiura Susumu 梶浦晋, and Professor Ochiai Toshinori 落合俊典 in 1999.

2) T. 606, p.215c2l-216 al

3) Т.602, p.165a3-6

4) Even DDJ is a extracted form when we compare with XXDDJ.

5) T607,p.235cl4-17

T606,p.212all-13 7) See Kusuyama Haruki 楠山春樹 ‘kan-go to-si-te no si-kan’ 漢 
The Newly Found Kongō-Ji Manuscript An-Ban Shou-Yi Jingl) and T602 Fo-Shuo Da An-Ban Shou-Yi Jing (H.L.Hung)

語としての止観 Si-kan no kenkyu p.187 iwa-nami syo-ten Tokyo

8) Chattha Sangāyama CD-Rom from Dhammgiri, version 1:1(India,Dharmmagiri:Vipassana Research Institute), Roman Vision:3.37-3.45

9) The term 聽說 translated by An Shigao appears 13 times in all his works. And the term 止意 translated by An Shigao appears 32 times. 10) However, 支謙, 康僧會, 曇果共康孟詳, 支婁迦識, 吳維祇難等 used this word frequently in their works. 11) Texts such as 佛說解十二門經, 八正道經, 佛說 大安般守意經，阿鋡口解十二因緣經 and 雜阿含經(T.101) 12) Aramaki Noritoshi 荒牧典俊. 1971. 'Indo bukkyo kara Chūgaku bukkyo he: An pan shu I kyo to Ko Soe, Doan, Sha Fu Jo nado’ インド仏教から中国仏教へ一安般守意経と康僧会・道安・謝敷序 など一. Bukkyo shigaku 仏教史学.15(2),p.140 13) Aramaki Noritoshi(1971), p.141 14）『大毘婆沙論』:「有修持來持去念 - 此中持來者・謂入息 $\cdot$ 持去者謂出息 $\cdots \cdot$ 有作是

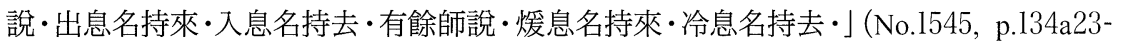
29） 15）『順正理論』：「言阿那者・謂持息入是引外風令入身義・阿波那者·謂持息 出是引內風令出身義 -...故名阿那阿波那念 - 有餘師說 - 言阿那者 - 謂能持來 • 阿波那者 謂能持去・」(No.1562, p.672c28-p.673 a4) 16） T.182l, p.417cl4-15 17) Shou yi qie you bu wei zhu de lun shu yu lun shi zhi yan jiu説一切有部為主的論書與論師之研究 p.625 18）「『大毘婆沙論』總集以後, 譬喻師從説一切有部中脱出, 自成經部, 也稱 為譬喻師・」Yin-sun Fa-shi(1992 p.362) 19) Prof. Florin Deleanu already pointed out that these two paragraphs are very similar and it's not unlikely that they belong to the same system of literature. See(2003) 'The Newly Found Text of the An Ban Shou Yi Jing Translated by An Shigao' Kokusai bukkyogaku daigakuin daigaku kenkyu kiyo 国際仏教 学大学院大学研究紀要6: p.152. 20) Kongo ji issaikyo no kisoteki kenkyu to sinsyutu butten no kenkyu 金剛寺一切経の基礎的研究と新出仏典の研究 p.188 for line number 6l-62 2l) 『出三藏記集』: 「或以口解。或以文傳」(T.2145,p.69c28)

22) [see Stefano ZaCCHetTi(2004b) 'Teaching Buddhism in Han China A Study of the Aban koujie Shi'er yinyuan jing (hereafter AFKJ) Tl508 Attributed to An Shigao' Annual Report of The international Research Institute for Advanced Buddology at Soka University for the Academic Year 2003 創価大学・国際仏教学高等研究所年報7].

$\langle$ Key Words〉 An-Ban Shou-Yi Jing Original Scripture Commentary (Assistant Prof. of Asia University, TAIWAN) 